\title{
Faces Delayed
}

National Cancer Institute

\section{Source}

National Cancer Institute. Faces Delayed. NCI Thesaurus. Code C120330.

A component of the Children's Memory Scale. A series of faces are presented one at a time. After a delay of about 30 minutes the child is asked whether or not each face was one of the faces on the initial list. 